$$
\begin{aligned}
& \text { بروسى رشد، فيزيولوزى و سيستم آنتى اكسيدانى زوفا تحت ثاثير مكنتوير ايمينغى }
\end{aligned}
$$

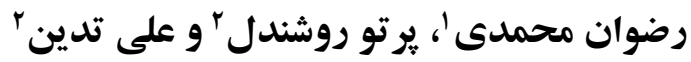

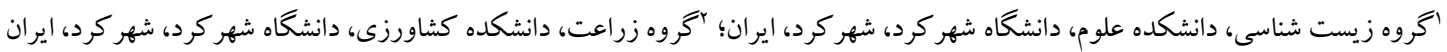

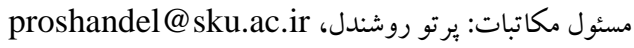

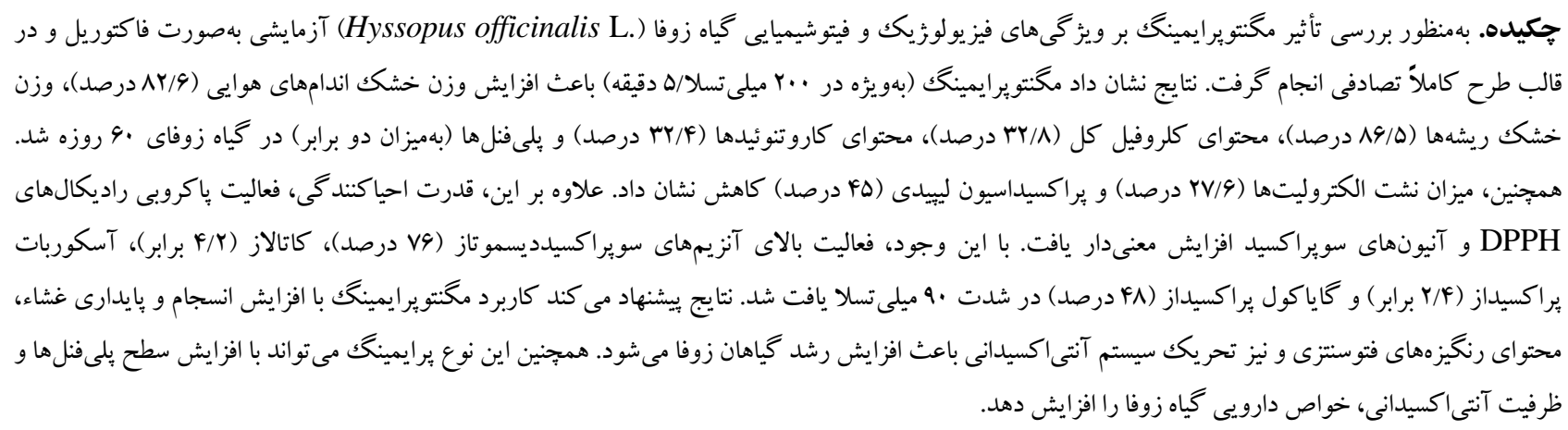$$
\text { وازه هاى كليدى. آنزيمهاى آنتى اكسيدان، يرايمينك بذر، فعاليت پإكروبى راديكالها، ميدان مغناطيسى، هيسويوس اوفيسيناليس }
$$

\title{
The effects of magnetopriming on the growth, physiology and antioxidant systems in hyssop
}

\author{
Rezvan Mohammadi ${ }^{1}$, Parto Roshandel ${ }^{2}$ \& Ali Tadayon ${ }^{2}$ \\ ${ }^{1}$ Department of Biology, Faculty of Sciences, Shahrekord University, Shahrekord, Iran; ${ }^{2}$ Department of Agronomy, \\ Faculty of Agriculture, Shahrekord University, Shahrekord, Iran \\ Correspondent author: Parto Roshandel, proshandel@ sku.ac.ir
}

\begin{abstract}
In order to study the effects of magnetopriming on the physiological and phytochemical characteristics of Hyssopus officinalis plants, this research was conducted as a factorial experiment in a completely randomized design. Results showed that magnetopriming (particularly at $200 \mathrm{mT} / 5 \mathrm{~min}$ ) increased the level of shoot dry weight $(82.6$ percent), root dry weight ( 86.5 percent), total chlorophyll (32.8 percent), carotenoids concentration ( 32.4 percent) and polyphenols content (2 folds) in 60-day-old Hyssopus officinalis. Also, electrolyte leakage and lipid peroxidation decreased by 27.6 and 45 percent, respectively. In addition, reducing power, DPPH and superoxide anion scavenging activities significantly augmented. However, higher activities of superoxide dismutase (76 percent), catalase ( 4.2 folds), ascorbate peroxidase ( 2.4 folds) and guaiacol peroxidase ( 48 percent) were found at $90 \mathrm{mT}$. Results suggested that the application of magnetopriming promoted growth in $\mathrm{H}$. officinalis through augmentation of cellular membrane integrity as well as biomass and photosynthetic pigments content. Furthermore, it was found to enhance the antioxidative system. Magnetopriming might apparently improve the medicinal properties via increasing the level of polyphenols and antioxidant capacity in H. officinalis.
\end{abstract}

Keywords. antioxidant enzymes, Hyssopus officinalis, magnetic field, radical scavenging activity, seed priming 
استفاده از برايمينگك با ميدان مغناطيسى بر روى رشد و نمو

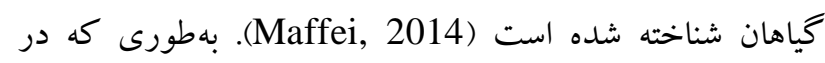

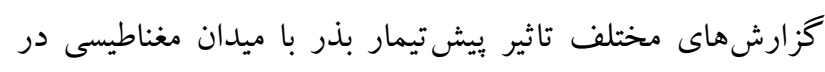

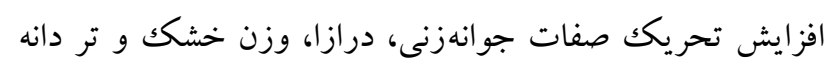

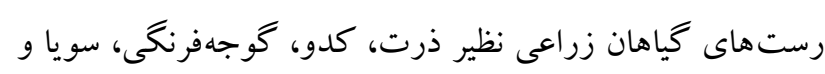

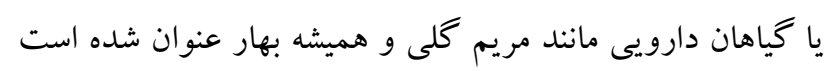
Yinan et al., 2005; Flórez et al., 2007; Martínez et ) .al., 2009; Flórez et al., 2012; Shine et al., 2012 علاوه بر اين، تاثير اين برايمينك بر تغييرات فيزيولوزيك و

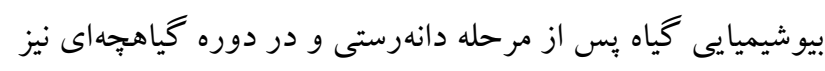
در شرايط عادى و يا تنش محيطى مورد مطالعه قرار گرفته است.

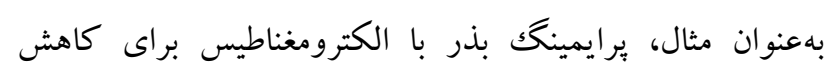

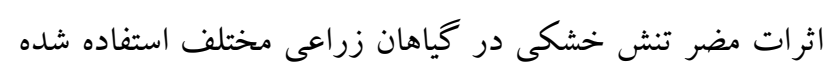

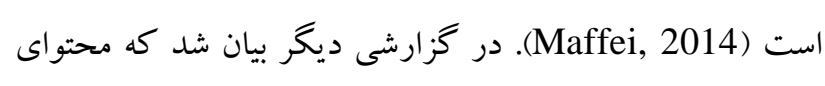

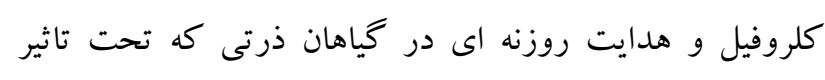

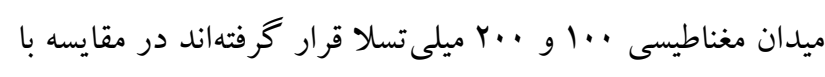

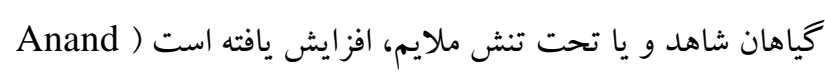

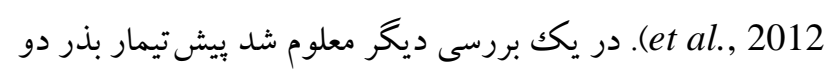

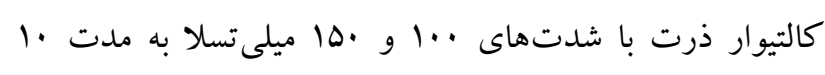
دقيقه باعث كاهش اثرات تنش خشكى از طريق بهبود وضعيت كلروفيل a و سيستمهاى خاموشى فتوشيميايى و غيرشيميايى مى -

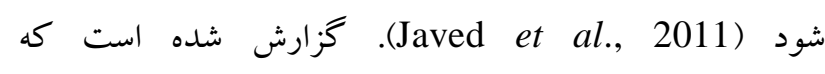
مكنتويرايمينگ بذر سويا بهبود دهنده رشد كالوس و آسيب

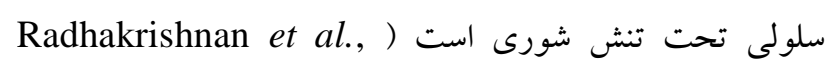

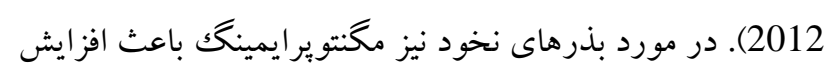
مقاومت به شورى اين كياه در مرحله جوانهزنى شد ( Thomas (et al., 2013

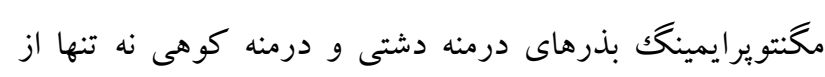
اثرات سوء تنش شورى در گياهجههاى رشد يافته اين خياهان

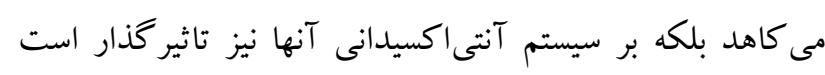
Azimian \& Roshandel, 2015; Roshandel \& ) (Azimian, 2015 مثبت ميدان مغناطيسى بر گياهان، در تحقيق حاضر تاثير

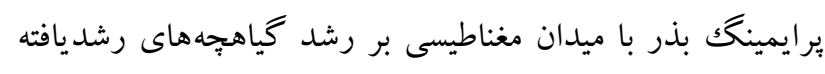

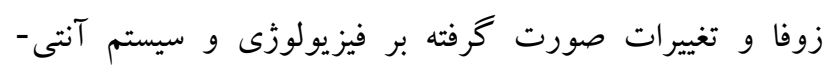

\section{مقدمله}

كياه زوفا (Hyssopus officinalis L.) از تيره نعنائيان 4. كياهى جند ساله است كه مىتواند تا ارتفاع (Lamiaceae)

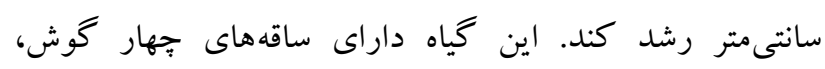

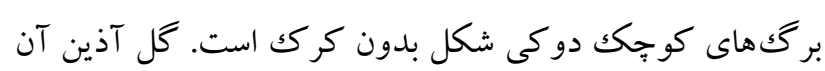

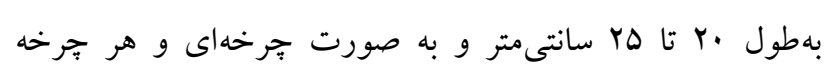

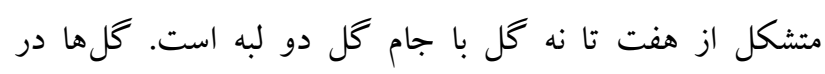

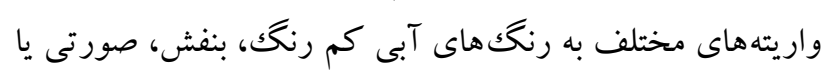

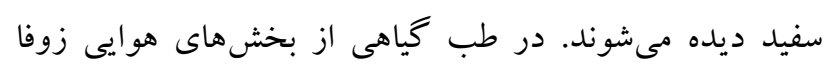
براى درمان بيمارى هاى مربوط به دستكاه تنفس مانند سرفه، سياه

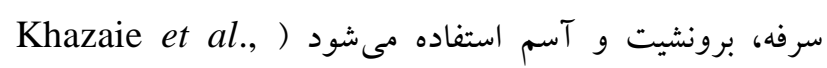

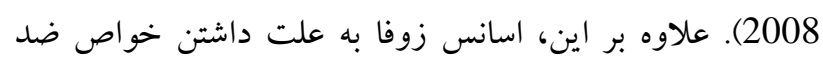

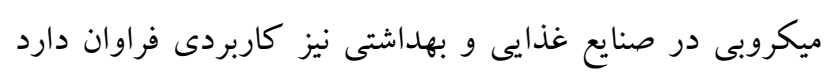
(Reichling et al., 2009) در گل هاى خود در رديف گياهان مولد عسل قرار مى گيرد. زوفا

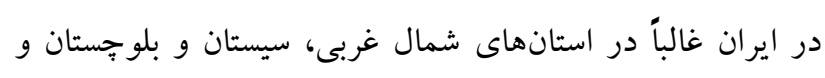
سو احل درياى خزر رويش طبيعى دارد.

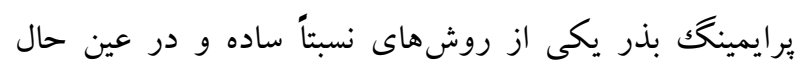

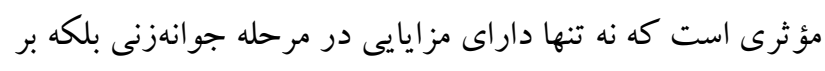

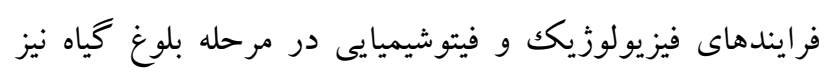

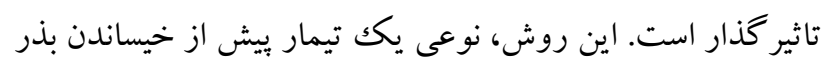

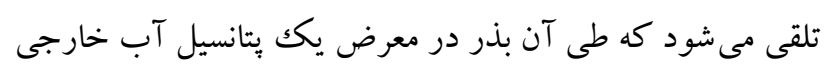

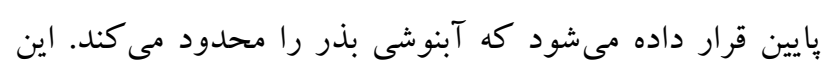

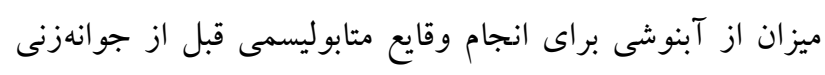

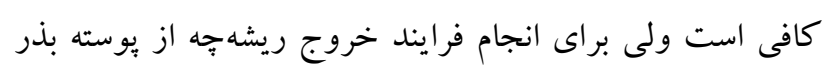

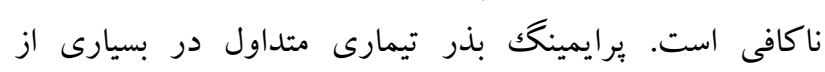

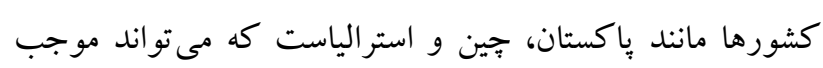

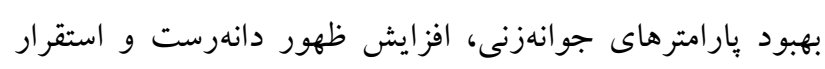

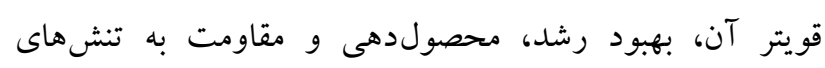
محيطى در شرايط نامطلوب شود (Ashraf \& Rauf, 2001). تاكنون اين تكنيك بهصور مختلف انجام شده است كه از آن

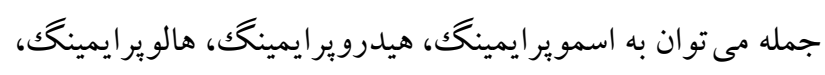

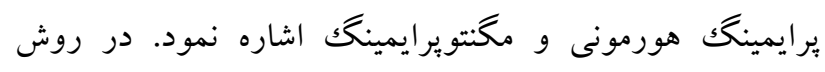

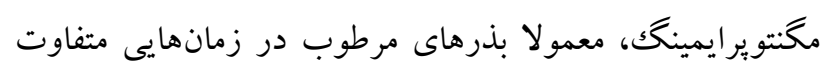

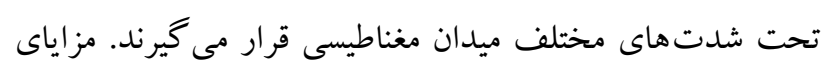




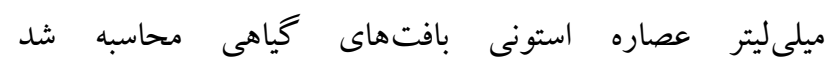

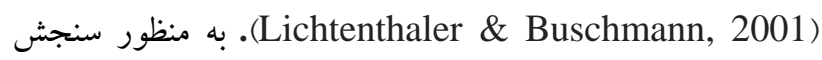
محتواى فنل كل و فعاليت آنتىاكسيدانى گياه تحت ميدان

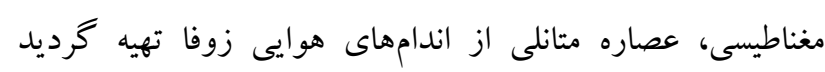

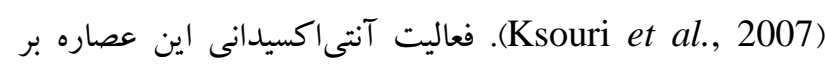

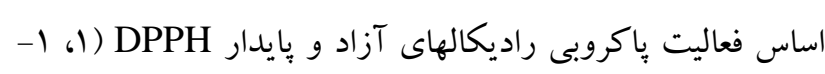

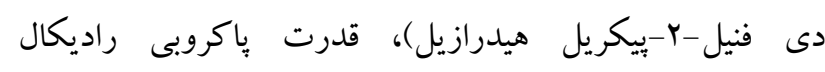

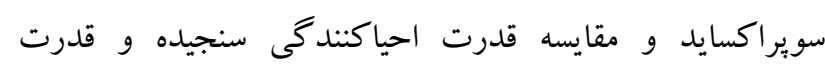

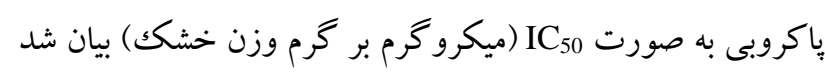
(Ksouri et al., 2007)

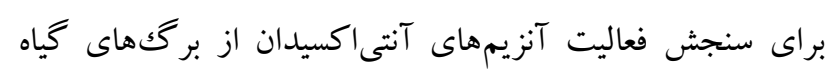

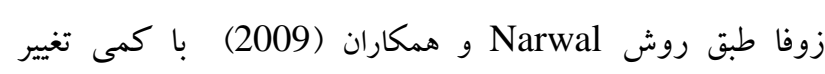

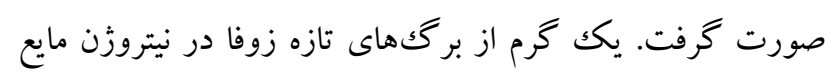

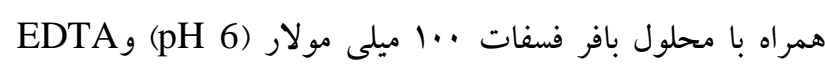

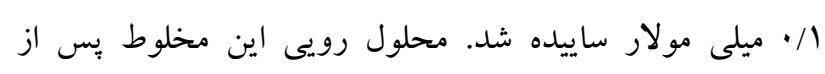

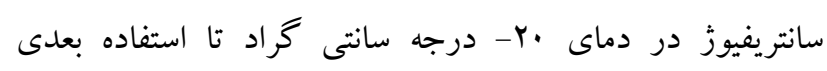
نخهدارى شد. براى اندازه گيرى فعاليت آنزيمهاى آنتى اكسيدان دردان

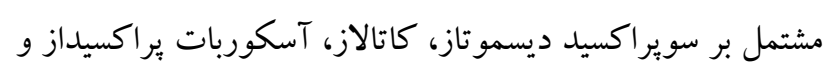
كاياكول يراكسيداز از روش Narwal و همكاران (2009) استفاده

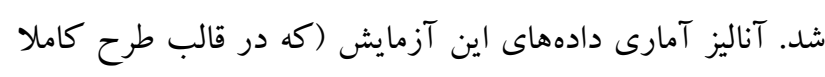

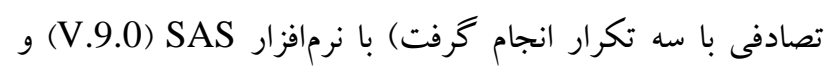

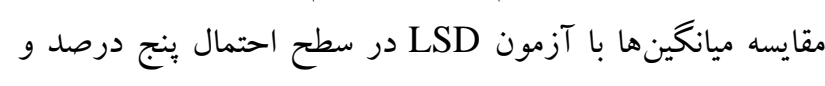

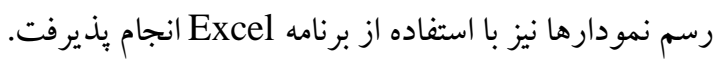

\section{نتايج}

تغيير در وزن خشك اندامهاى هوايى

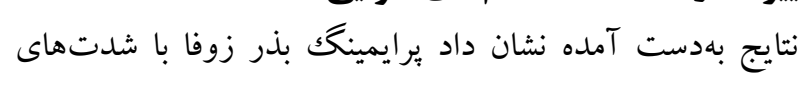

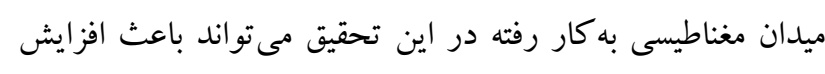

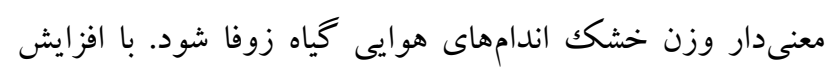

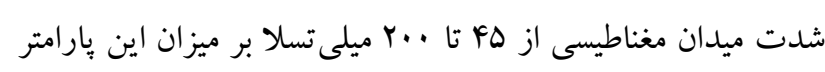

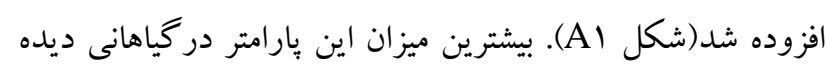

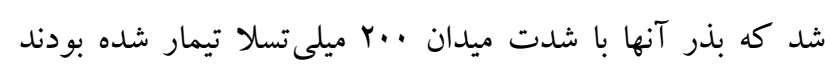

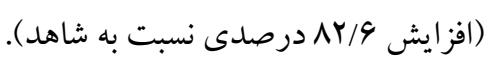

تغيير در وزن خشك ريشهها

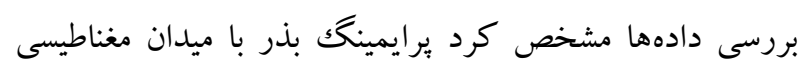

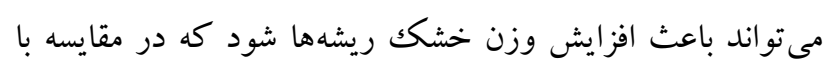

اكسيدانى آنزيمى و غير آنزيمى آن در شرايط عادى (بدون تنش) مورد بررسى قرار خرفته است.

مواد و روشها آماده سازى و شرايط رشد

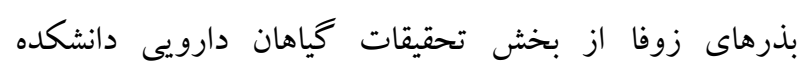

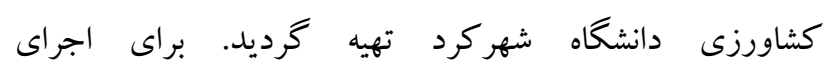

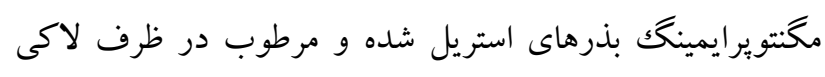
مكعبى با ابعاد يكك سانتىمتر مكعب در شكاف دستخاه مولد ميدان

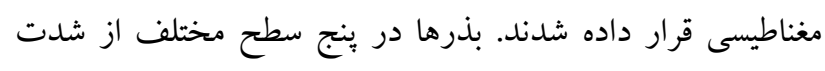

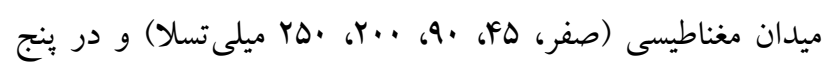

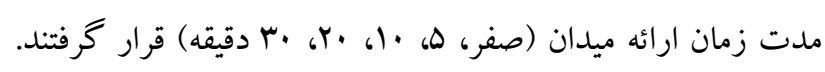

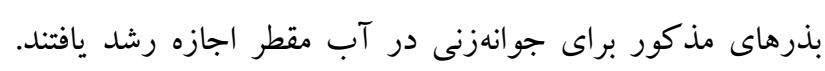

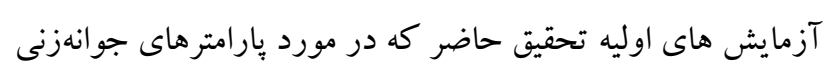

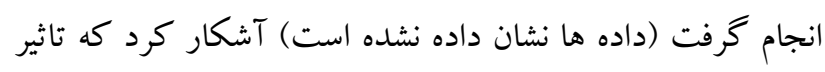

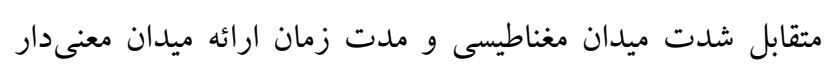

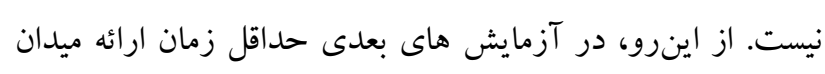

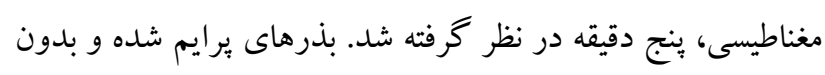

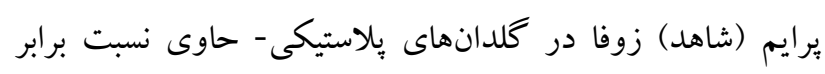

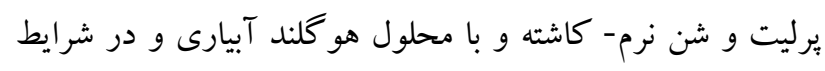

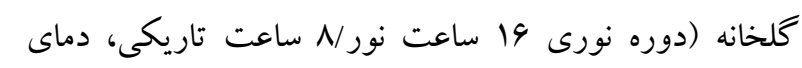

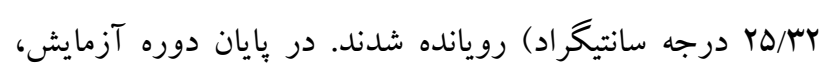

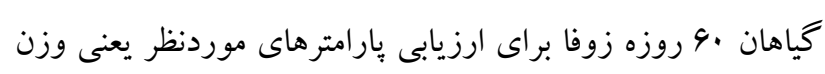

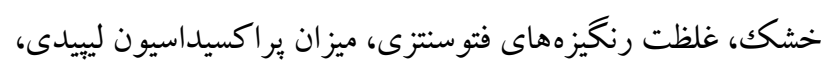
نشت الكتروليتى غشاء، محتواى فنل كل، سيستم آنتىاكسيدانى

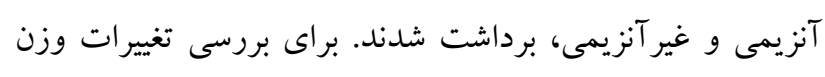

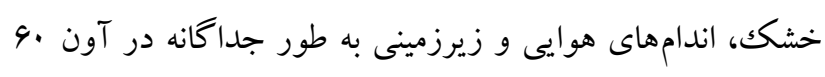

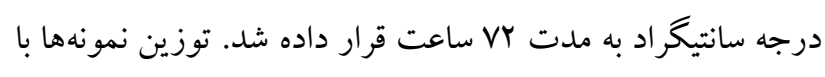

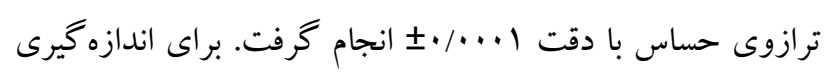

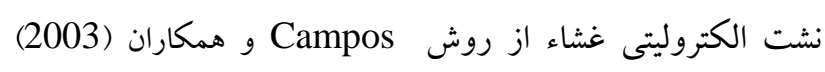

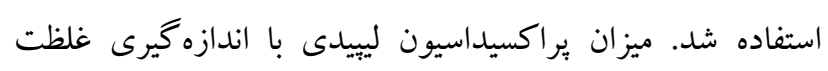

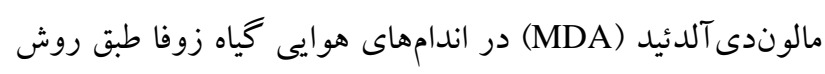
Ksouri

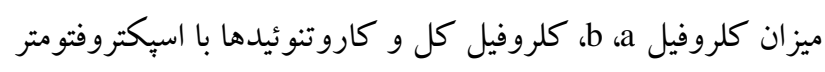

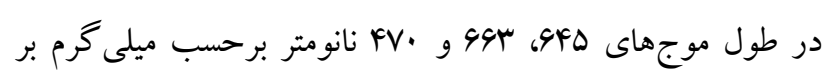


شدت ميدان مغناطيسى كه اختلاف معنىدارى با شاهد داشت

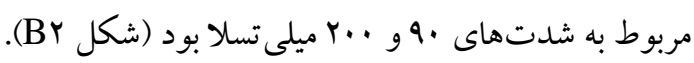

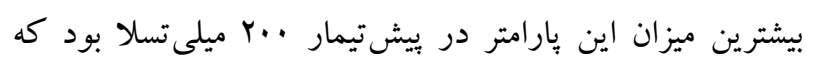

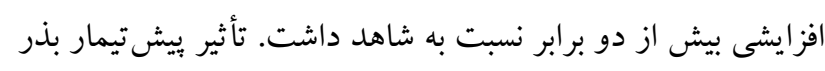

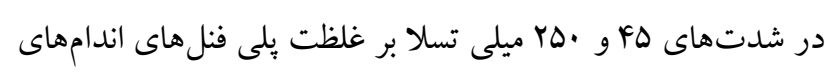
هوايى زوفا تأثير معنى دارى نداشت. علاوه بر اين، تفاوتى معنى دار براى محتواى كلروفيل b دراين دو شدت ميدان نيز بهدست آمد.

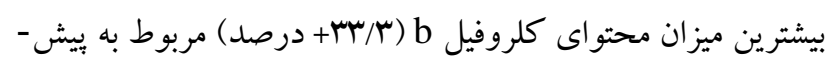

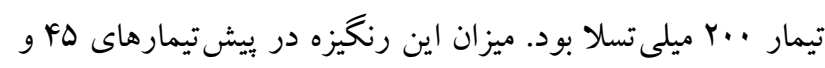
• ه r ميلى تسلا تفاوت معنى دارى با شاهد نداشت. محتواى كلروفيل كل در كياهان زوفا نيز تحت تأثير شدت ميدان مغناطيسى از روندى نسبتاً مشابه برخوردار بود (شكل Cr). بهطورى كه بيشترين

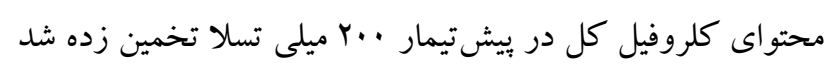

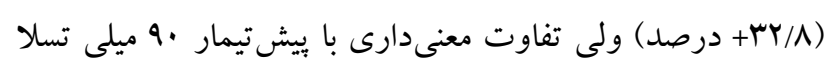

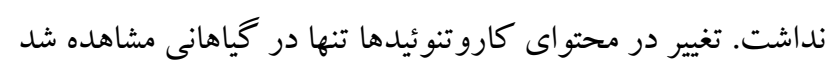

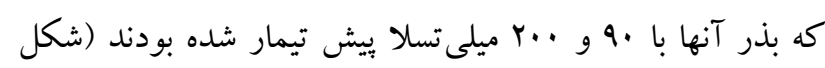
Dr قابل ملاحظه و معنىدارى را براى اين بارامتر بهدنبال نداشت.

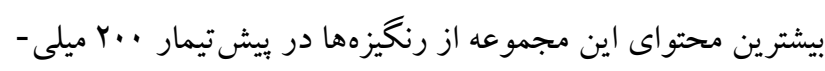
تسلا با افزايش

\section{تغيير در ميزان فنل كل}

نتايج مشخص كرد كه بيش تيمار بذرهاى زوفا با ميدان مغناطيسى ميز مى تواند بر ميزان فنل كل بخشهاى هوايى اين كياه مؤثر باشد. نتايج نشان دادكه ميزان فنل كل اندامهاى هوايى در كياهان بيش -

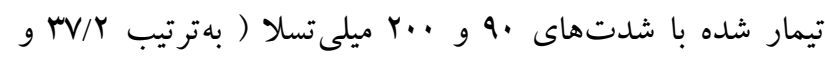

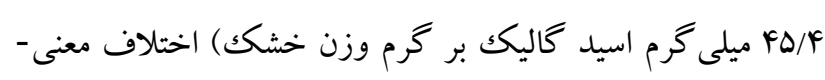

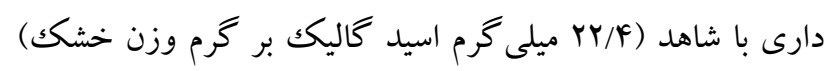

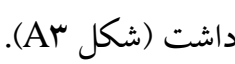

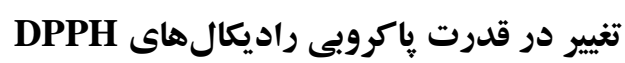

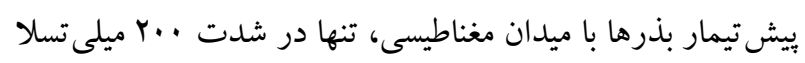

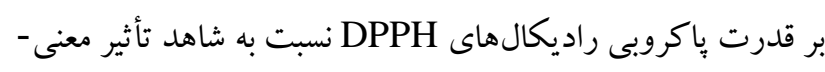

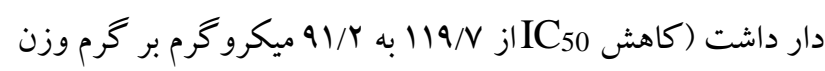

تغيير در فعاليت ڤاكروبى آنيونهاى سويراكسيد

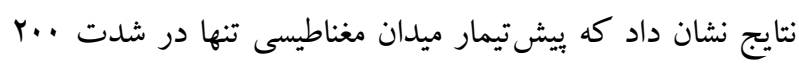

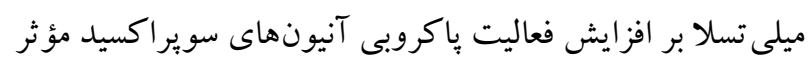

شاهد اختلاف معنىدار نيز وجود داشت (شكل (B)). همشام با افزايش شدت ميدان مغناطيسى از FD تا . . م ميلى تسلا بر ميزان اين roارامتر افزوده شد ولى در بذرهاى تيمار شده با شدت ميدان ميلى تسلا از وزن خشك ريشه ها به طور معنىدار كاسته شد. وزن

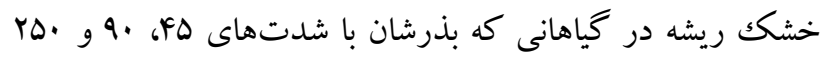
ميلى تسلا يرايم شده بودند اختلاف معنىدارى با يكديكر نداشت. به اين ترتيب مؤثرترين شدت ميدان مغناطيسى براى افزايش

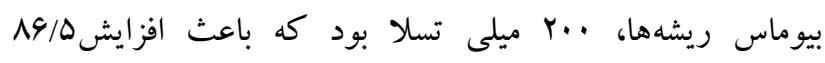
درصدى اين يار امتر نسبت به شاهد شد. تخيير در يراكسيداسيون ليييدى نتايج معلوم كرد اعمال ميدان مغناطيسى در تمام شدت هائيون به كار رفته مىتواند به صورت معنى دار از شدت يراكسيداسيون ليِيدهاى غشايى بكاهد (شكل Cl). ميزان اين كاهش از 9 ادرصد (در

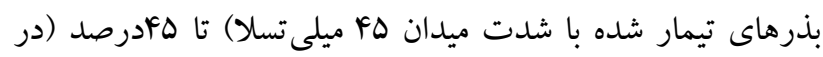
بذرهاى تيمار شده با شدت ميدان ·. . ميلى تسلا) متفاوت بود.

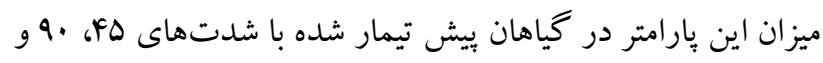
. له r ميلى تسلا تفاوت معنى دارى نشان نداد.

تغيير در ميزان نشت الكتروليتى غشاء

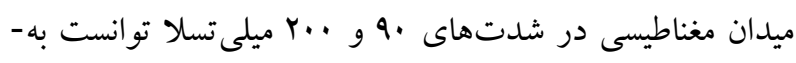
طور معنىدار نشت الكتروليتها از غشاءهاى سلولى را به ترتيب از

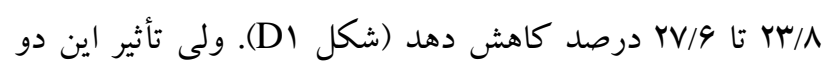
شدت ميدان مغناطيسى با يكديخر اختلاف معنى دارى نداشت. با داصن اين وجود، ميزان نشت الكتروليتها در شدت ميدان مغناطيسى مهان و · ro ميلى تسلا اختلاف معنى دارى با كياهان شاهد نداشت.

\section{تغيير در ميزان رنتيزههاى فتوسنتى}

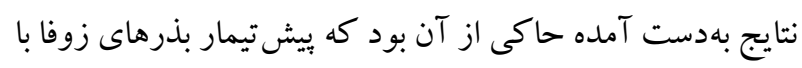
ميدان مغناطيسى مى تواند بر محتواى كلروفيل a در كياهان اين گونه تأثير گذار باشد (شكل Ar). با اين وجود، ميزان اين تأثير در شدت هاى مختلف ميدان متفاوت بود. بهعبارت ديخر، در حالى كه

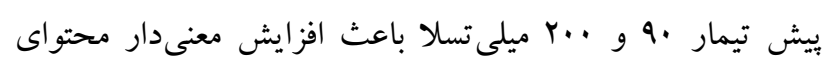
كلروفيل a نسبت به كياهان شاهد شد ولى محتواى اين رنكيزه در

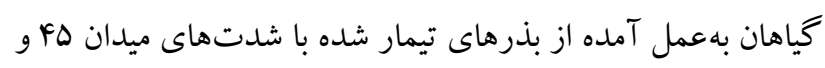
•ه r ميلى تسلا اختلاف معنى دارى با خروه شاهد نداشت. بيشترين

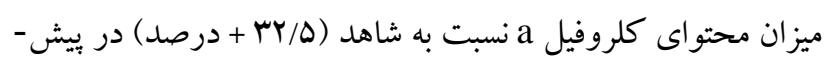
تيمار · ·. ميلى تسلا بهدست آمد. براى كلروفيل b نيز بيشترين تأثير 

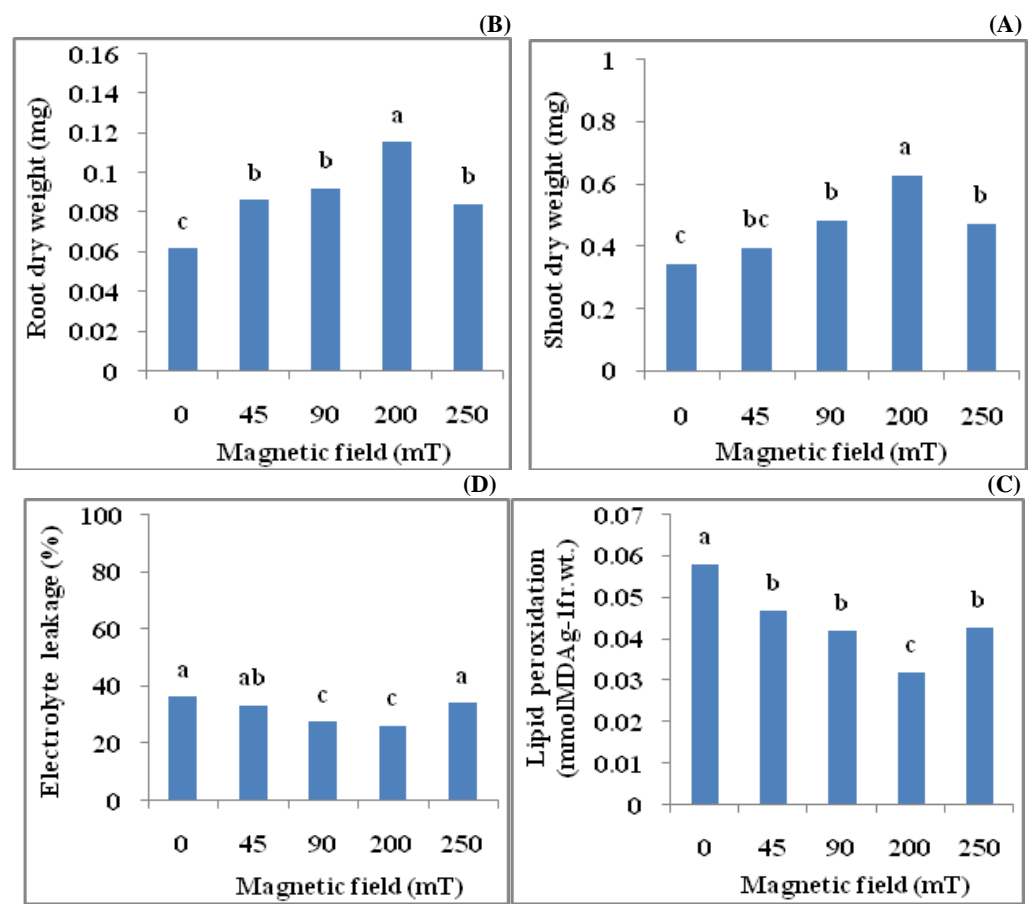

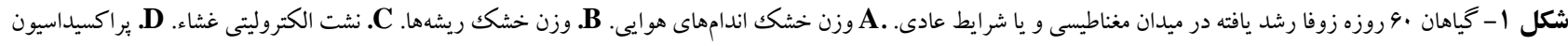

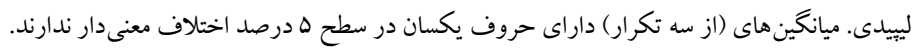

Fig. 1. 60-day-old Hyssopus officinalis plants primed with magnetic field and grown under normal condition. A. Shoot dry weight. B. Root dry weight. C. Electrolyte leakage. D. Lipid peroxidation. Means (three replicates) with the same letter are not significantly different at $\mathrm{p}<0.05$.
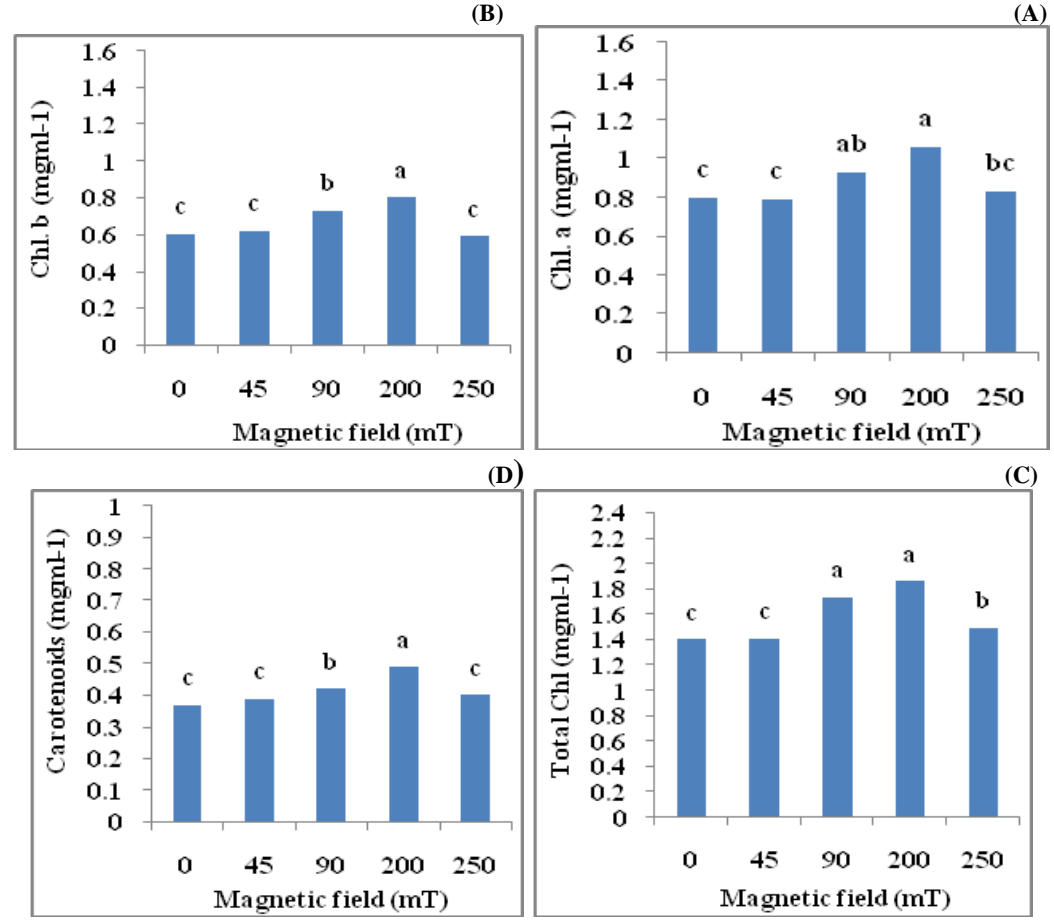

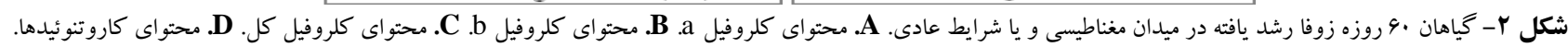

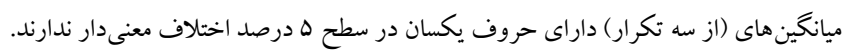

Fig. 2. 60-day-old Hyssopus officinalis plants primed with magnetic field under normal condition. A. Chlorophyll a content. B. Chlorophyll b content. C. Total chlorophyll content. D. Carotenoids content. Means (three replicates) with the same letter are not significantly different at $\mathrm{p}<0.05$. 
هيدروزن بر دقيقه بر ميلى گرم يروتئين) فعاليت آنزيم كاتالاز

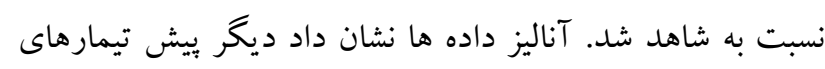

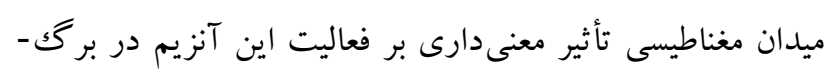
هاى زوفا نسبت به شاهد ندارد.

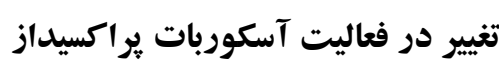

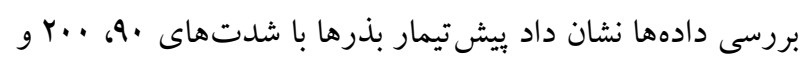

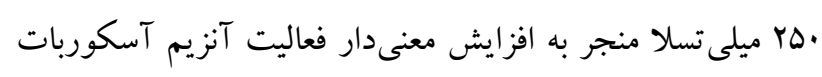

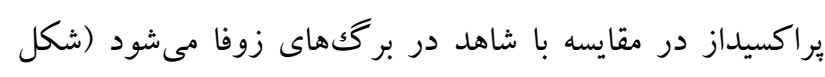
نج

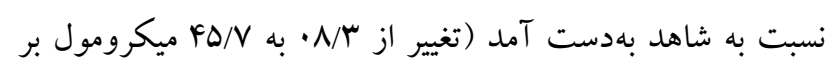

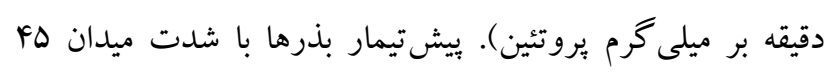

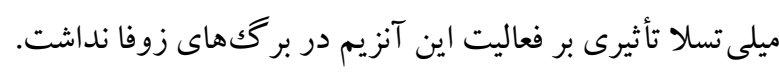

\section{تغيير در فعاليت تاياكول يراكسيداز}

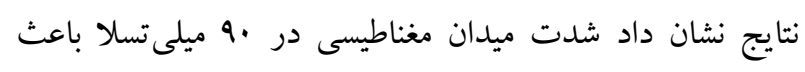

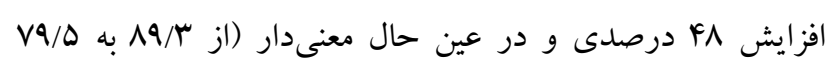

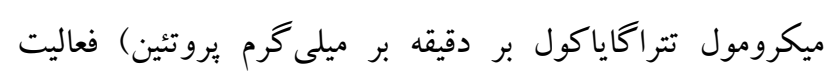

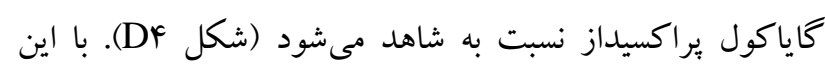

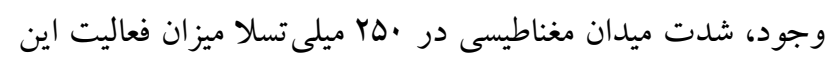

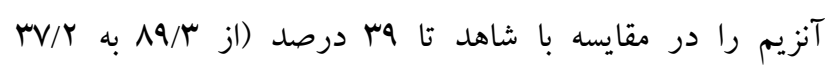
ميكرومول تتراكاياكول بر دقيقه بر ميلى گرم بروتئين) كاهش داد داد.

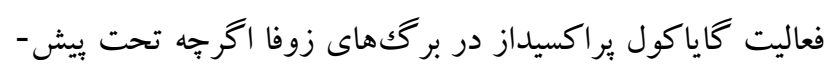

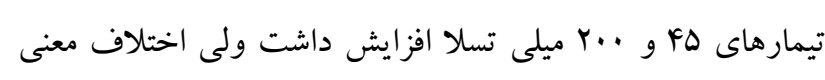
دارى با شاهد براى اين دو گروه بهدست نيامد.

\section{بحث}

مطالعات متعددى وجود دارد كه تاثير ميدان مغناطيسى را بر روى

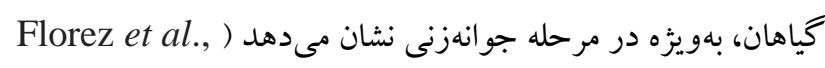
2007, 2012; Martínez et al., 2009; Radhakrishnan et al., 2012; Radhakrishnan \& Kumari, 2013; Shine et al., 2012; Thomas et al., 2013; Baser Kouchebagh et واسته

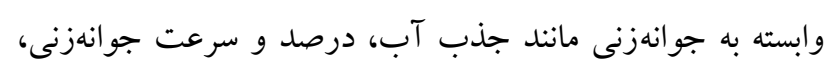
وزن خشك، تر و طول دانهرست و شاخص هاى بنيه بذر به گونهاى مثبت تحت تاثير ميدان مغناطيسى قرار مى گيرند. دادههاى تحقيق حاضر نشان داد كه برايمينگك بذر با ميدان مغناطيسى مى تواند ماند

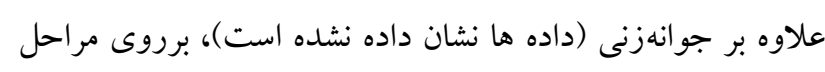

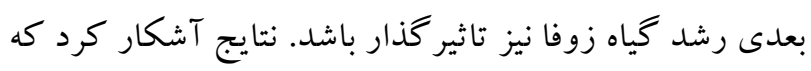

است (شكل Cr). اين افزايش نسبت به شاهد معنىدار بود. به

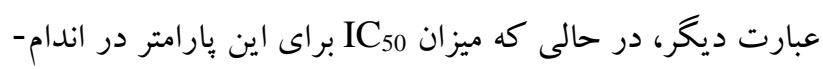

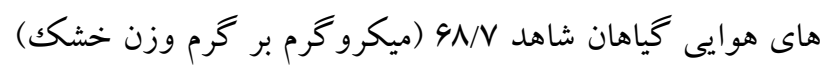

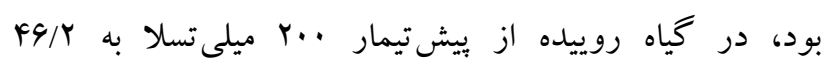
(ميكرو گرم بر گرم وزن خشكى) كاهش يافت (

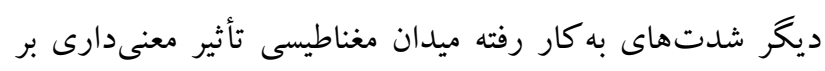

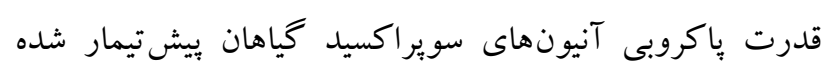

\section{نداشت.}

\section{تغيير در قدرت احياكنندكى}

نتايج معلوم كرد بيش تيمارهاى ميدان مغناطيسى در شدوت

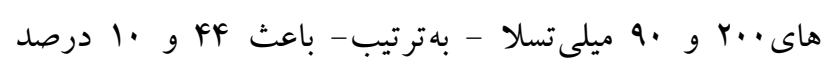

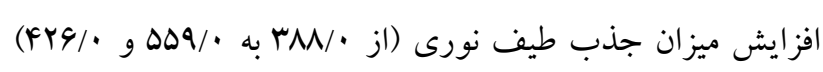

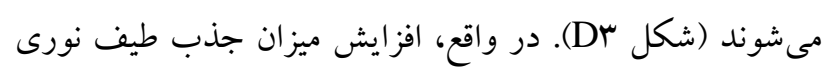

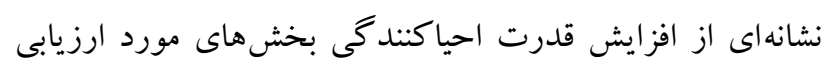

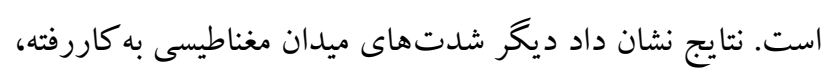

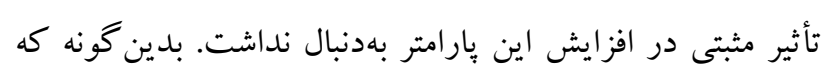

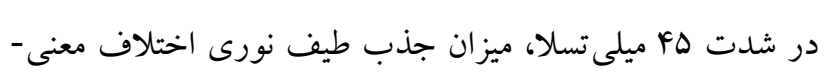

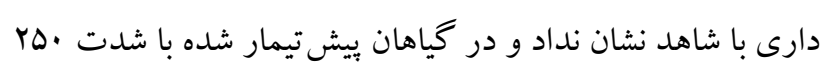

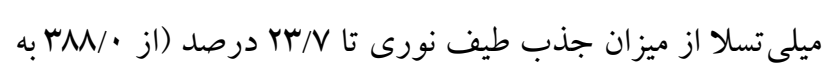
(Y99/.

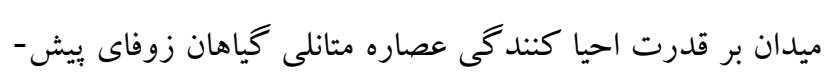
تيمار شده در اين شدت ميدان باشد.

تغيير در فعاليت سوير اكسيد ديسموتاز

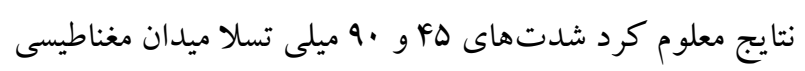

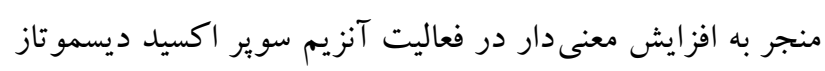

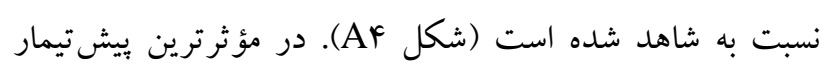

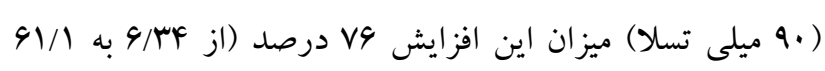

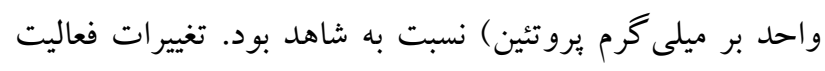

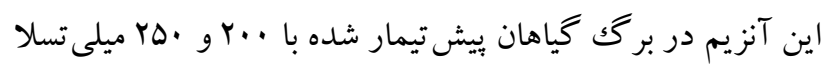
تفاوت معنى دار با شاهد نداشت.

تغيير در فعاليت كاتالاز نتايج حاكى از آن بود كه بيش تيماليت كالازبذر باز باز ميدان مغناطيسى

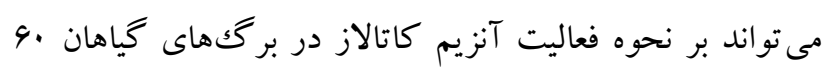

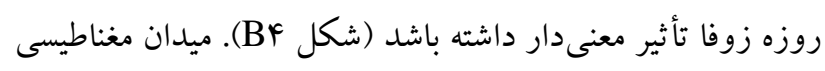

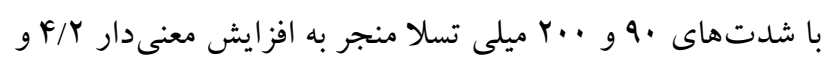

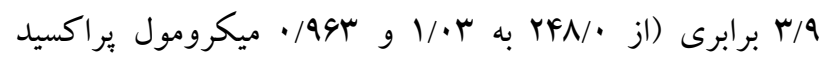


(B)

(A)
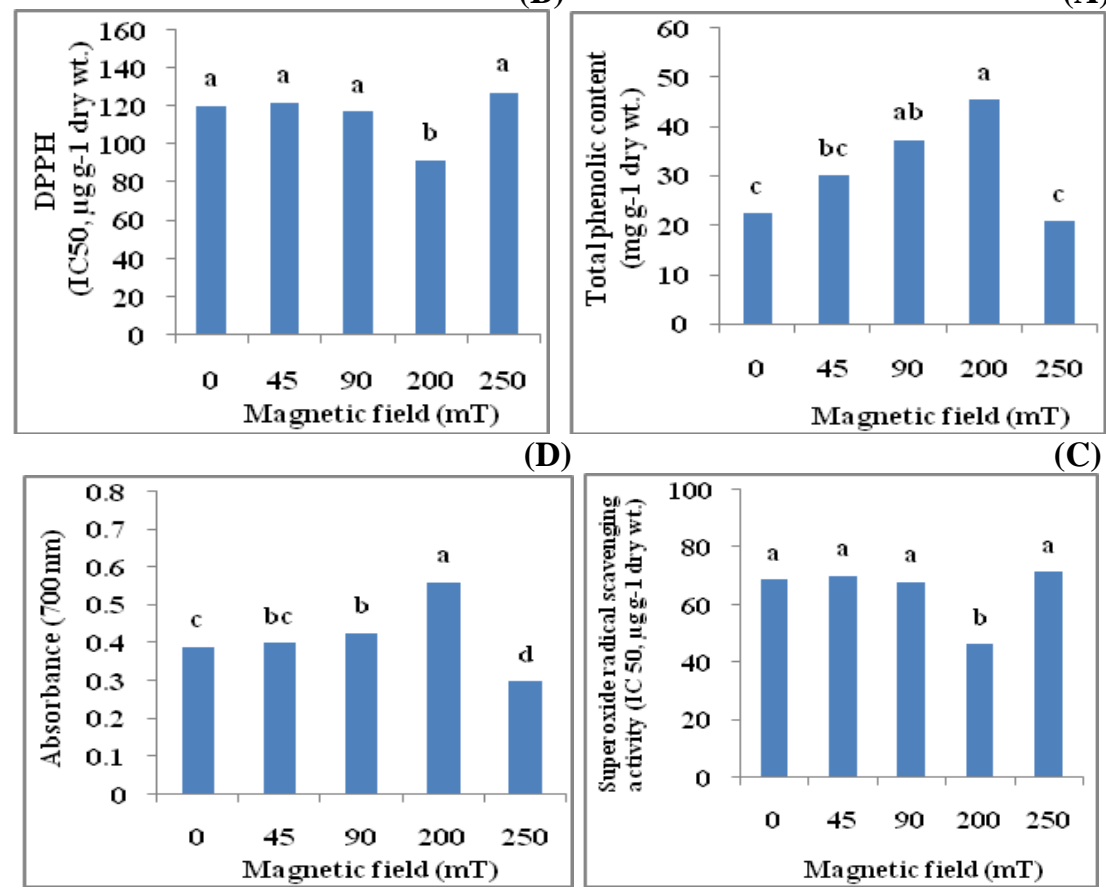

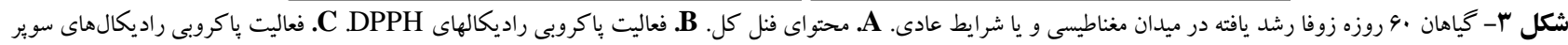

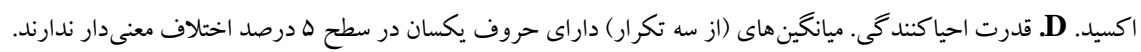

Fig. 3. 60-day-old Hyssopus officinalis plants primed with magnetic field under normal condition. A. Total phenolic content. B. DPPH radical scavenging activity. C. Superoxide anion radical scavenging activity. D. Reducing power. Means (three replicates) with the same letter are not significantly different at $\mathrm{p}<0.05$.

(B)
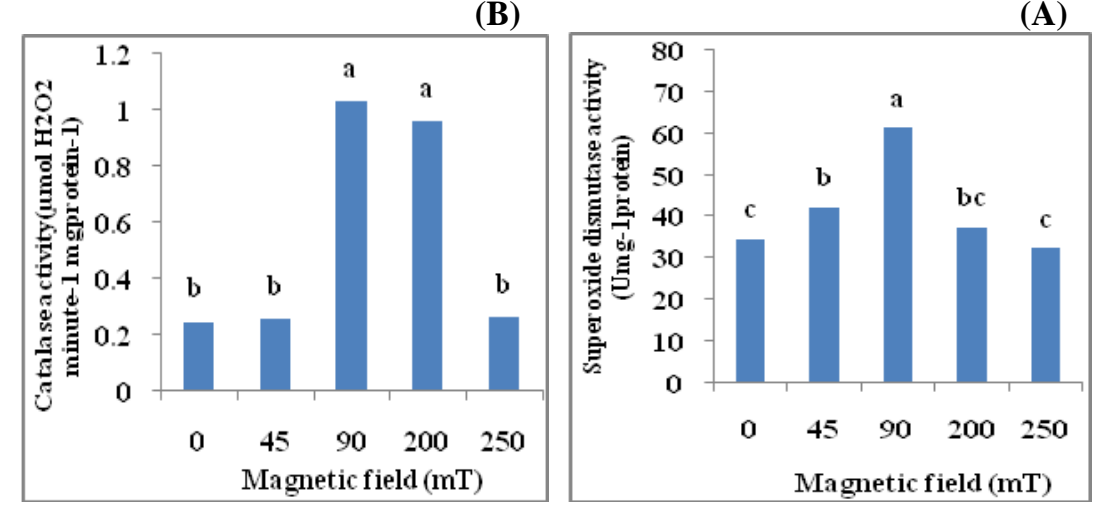

(D)
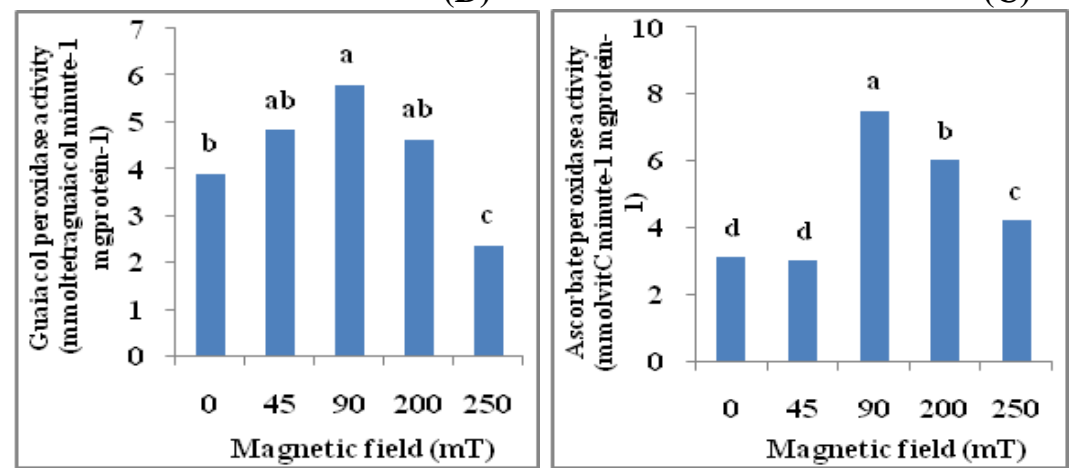

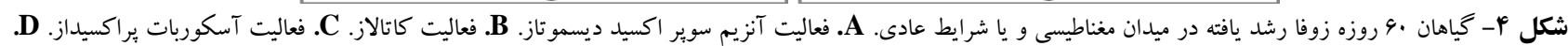

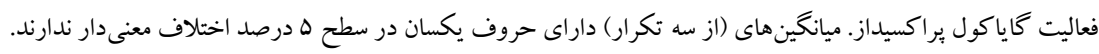

Fig. 4. 60-day-old Hyssopus officinalis plants primed with magnetic field under normal conditions. A. Superoxide dismutase activity. B. Catalase activity. C. Ascorbate peroxidase activity. D. Guaiacole peroxidase activity. Means (three replicates) with the same letter are not significantly different at $\mathrm{p}<0.05$. 
Kavi, ) افزايش مىدهد و فعاليتهاى فتوسنتى را ارتقاء مىبخشد

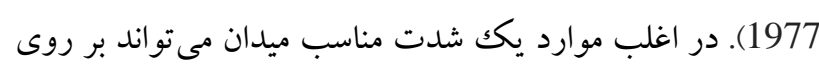

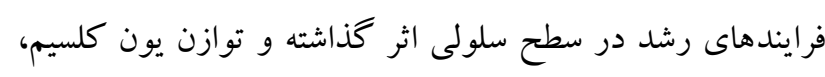

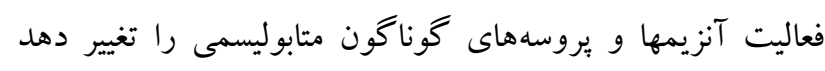

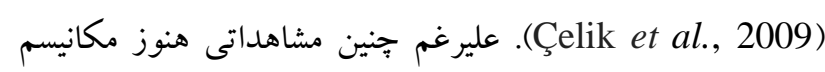
دقيق واكنش ميدان مغناطيسى با يكك سلول زنده نامعلوم باقى مانده

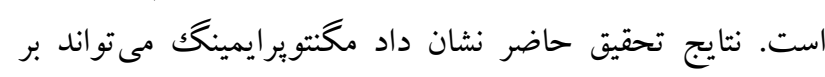

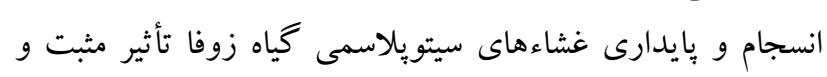

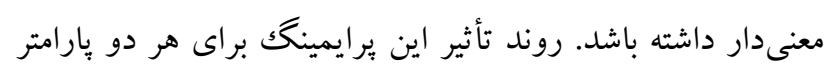

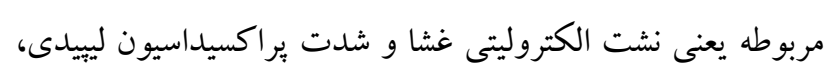

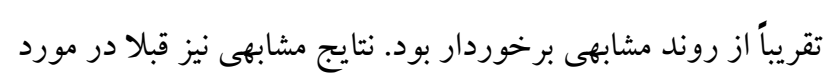

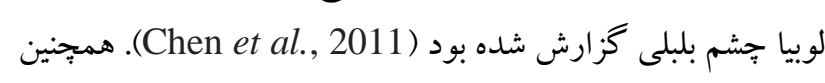
نتايج آشكار كرد كه تأثير مثبت ميدان مغناطيسى بر بايدارى غشاء - نائل

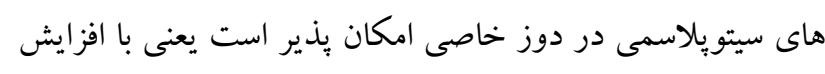

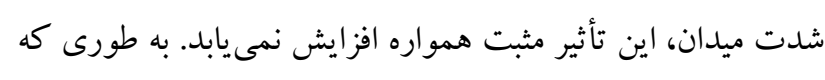

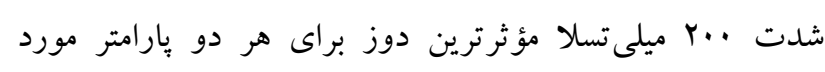

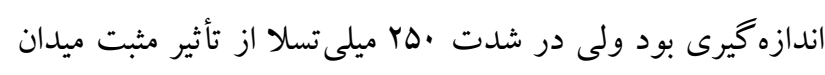
مغناطيسى كاسته شد. افزايش محتواى فنل كل و ظرفيت آنتى اكسيدانى اندامهاى

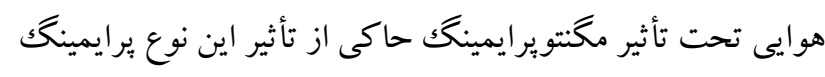

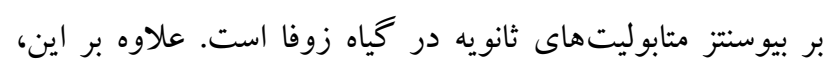

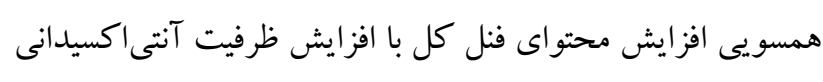

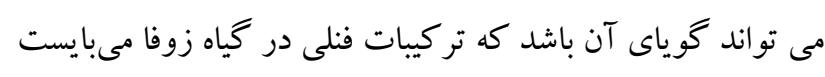

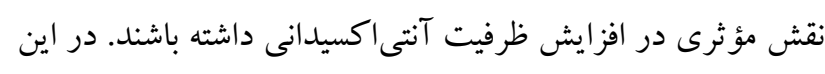

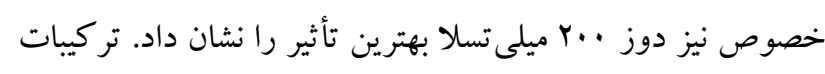

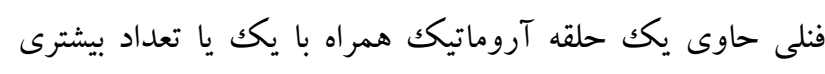

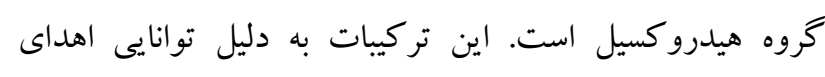

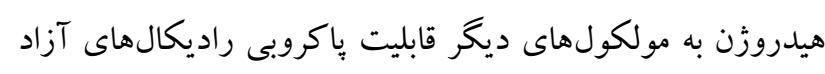

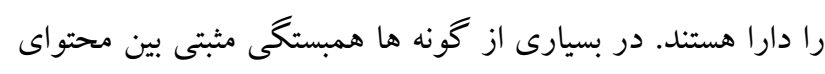
نا

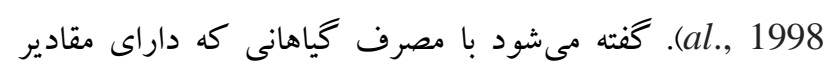

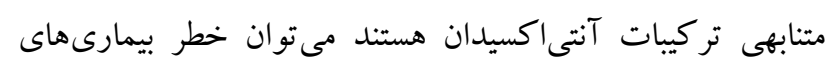

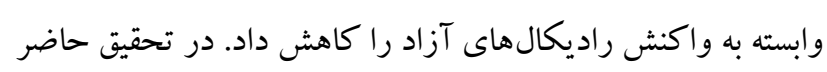

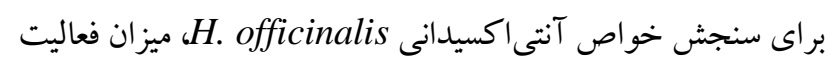
ياكروبى راديكالهاى DPPH و آنيونهاى سوير اكسيد و نيز قدرت إنى
مكنتوير ايمينگك مى تواند بر افزايش بيوماس گياهان زوفا مؤثر باشد. اين تأثير مثبت در هر دو بخش اندامهاى هوايى و زيرزمينى مشاهده

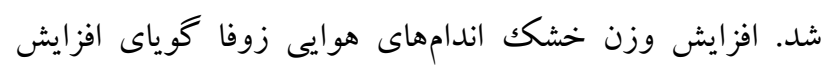

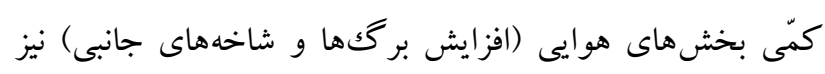

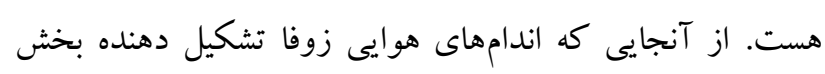

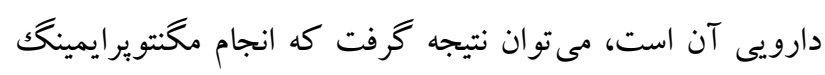

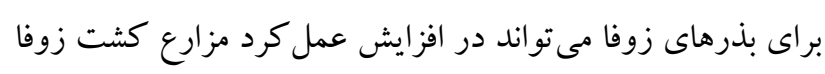

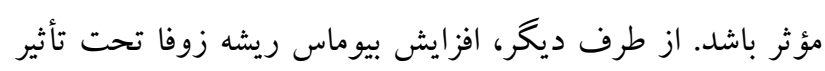

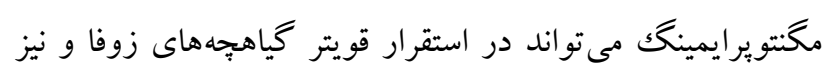
جذب آب و املاح معدنى بيشتر و در نتيجه رشد بهتر اين كئن

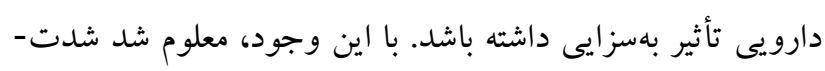

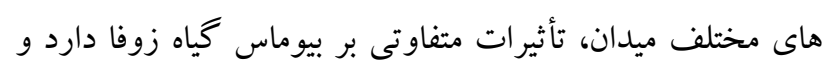

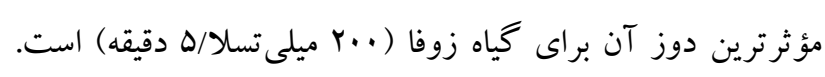

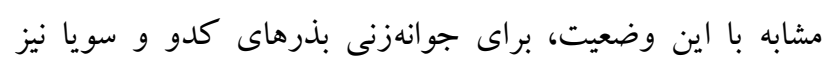

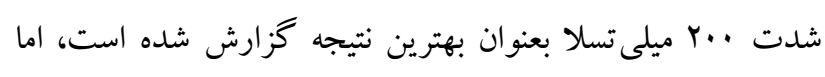
مؤثرترين زمان ارائه ميدان يكك ساعت بوده است ( Bhardwaj et تجفقات 2012

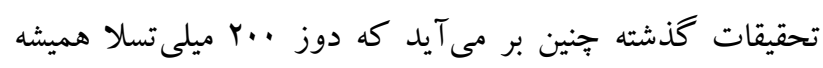

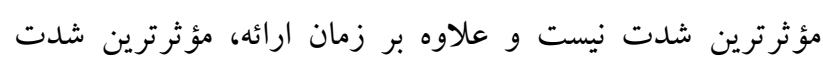

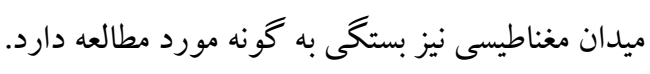

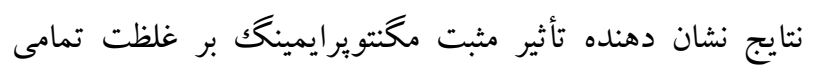

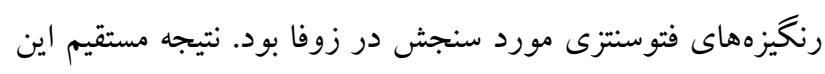

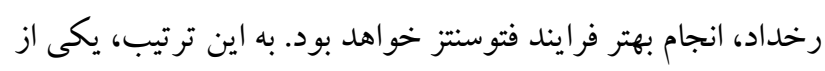

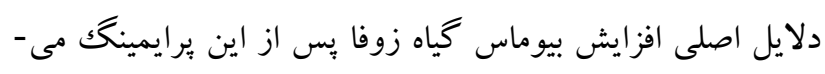

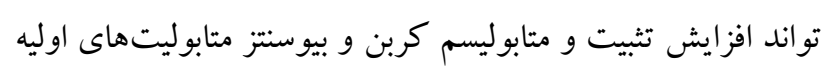

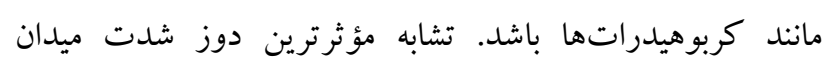

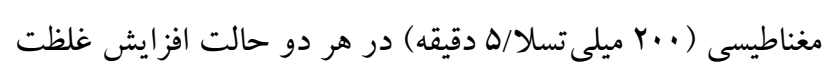

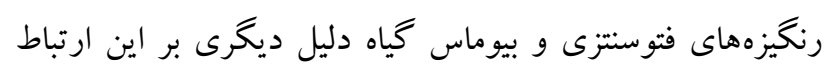

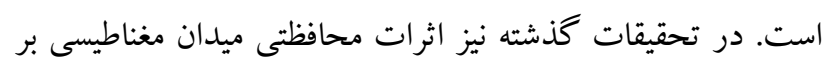

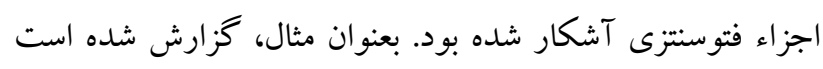

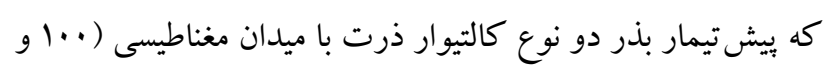

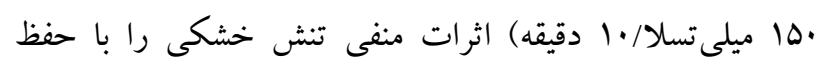

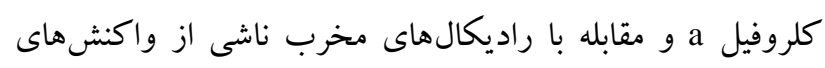

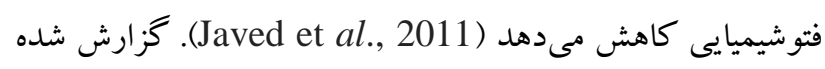
است كه تيمار مغناطيسى مناسب، جذب و مت متابوليسم مواد غذايى را 


\section{نتيجاه كيرى}

نتايج يُزوهش حاضر نشان داد برايمينگك بذر زوفا با ميدان

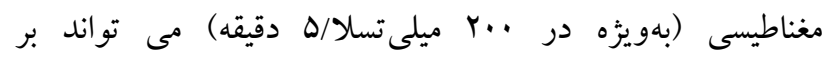
فيزيولوزى و فيتوشيمى گياهان رشد يافته از اين بذرها مؤثر باشد.

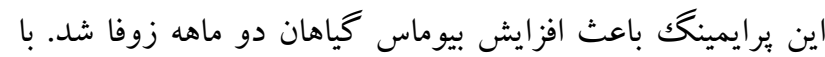
توجه به دادههاى تحقيق حاضر مىتوان كفت تأثير مثبت ميدان

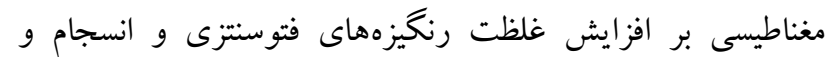

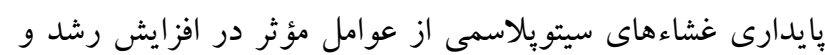

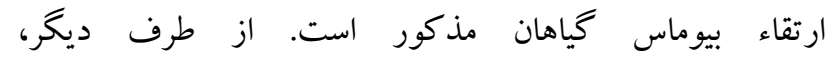

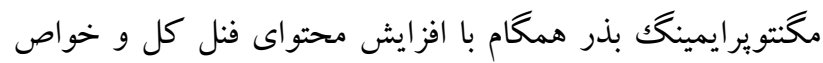

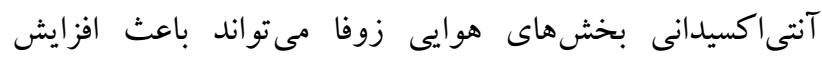

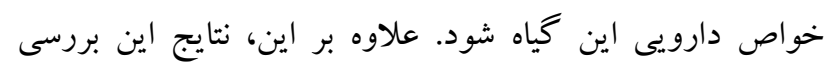

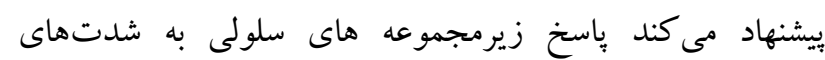
مختلف ميدان مغناطيسى مى تو اند متفاوت باشد.

\section{سياسگز ارى}

نويسند كان از بخش فيزيكك دانشكده علوم دانشگاه شهر كرد به

$$
\text { ويزه د كتر محمد مر ادى قدردانى مى نمايند. }
$$

\section{REFERENCES}

Alemán, E.I., Mbogholi, A., Boix, Y.F., GonzálezOlmedo, J. and Chalfun-Junior, A. 2014. Effects of EMFs on some biological parameters in coffee plants (Coffea arabica L.) obtained by in vitro propagation. - Development 8: 14.

Anand, A., Nagarajan, S., Verma, A.P.S., Joshi, D.K., Pathak, P.C. and Bhardwaj, J. 2012. Pre-treatment of seeds with static magnetic field ameliorates soil water stress in seedlings of maize (Zea mays L.). - Indian J. Biochem. Biophys. 49: 63-70.

Ashraf, M. and Rauf, H. 2001. Inducing salt tolerance in maize (Zea mays L.) through seed priming with chloride salts: Growth and ion transport at early growth stages. - Acta Physiol. Plant. 23: 407- 414.

Azimian, F. and Roshandel, P. 2015. Magnetic field effects on total phenolic content and antioxidant activity in Artemisia sieberi under salinity. - Indian J. Plant Physiol. 20: 264-270.

Baser Kouchebagh S, Rasouli P, Hossein Babaiy A, Khanlou A.R. 2015. Seed germination of pot marigold (Calendula officinalis L.) as affected by physical priming techniques. - Int. J. Biosci. 6: 49-54.

Bhardwaj, J., Anand, A. and Nagarajan, S. 2012. Biochemical and biophysical changes associated with magnetopriming in germinating cucumber seeds. Plant Physiol. Biochem. 57: 67-73.
احياكنندگى عصاره متانلى بخشهاى هوايى زوفا مورد ارزيابى قرار گرفت. اين تكنيكها از متداولترين روشها براى مطالعه

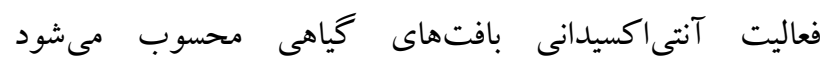

.(Kumaran \& Joel Karunakaran, 2007) مخنتويرايمينگك فعاليت آنزيمهاى آنتى اكسيدان كياه زوفا را نيز تحت تاثير خود قرار داد. بهطورى كه هر دو تأثير افزايشى و كاهشى معنى -دار در مقايسه با شاهد، در شدتهاى متفاوت ميدان مغناطيسى مشاهده شد. با اين وجود، دوز مؤثر براى بايهريزى بالاترين افزايش در فعاليت آنزيمهاى آنتى اكسيدان ( •9 ميلىتسلا) با مؤثرترين دوز مربوطه به ساير يارامترها مانند وزن خشك ساقه و ريشه، نشت الكتروليتى، ميزان مالوندى آلدئيد، محتواى فنل كل و ظرفيت آنتى اكسيدانهاى غير آنزيمى ( ... ميلى تسلا)، همخوانى نداشت. اين امر نشان مىدهد تاثير شدتهاى مختلف ميدان مغناطيسى بر اجزاء متفاوت سلولى، يكسان نيست. شدت ميدان

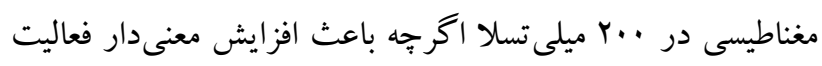
آنزيمهاى آنتى اكسيدان (بهويثه آسكوربات يراكسيداز و كاتالاز)، نسبت به شاهد شد ولى اين افزايش نسبت به شدت ·ه ميلى تسلا به نحو معنىدارى كمتر بود. تاثير ميدان مغناطيسى روى كياهان به واكنش راديكالهاى آزاد داراى الكترون اضافى در غشاءها نسبت داده شده است كه توليد ROS را تحريك مى نمايد. مطابق با نتايج تحقيق حاضر، مطالعات قبلى نيز ثابت كرده بود ميدان مغناطيسى مى تواند فعاليت آنزيمهاى پاكروبى نظير كاتالاز، سويراكسيد ديسموتاز، كلو تاتيون ردو كتاز، كلوتاتيون ترانسفراز، يراكسيدازها و ويلى فنل اكسيدازها را تغيير دهد ) Alemán et al., 2014; (Haghighat et al., 2014 كه تغيير فعاليت آنزيمهاى آنتى اكسيدان توسط ميدان مغناطيسى به دليل تجمع ROS توليد شده در اثر ميدان مغناطيسى است. بيشنهاد شده است اجزاء آيويلاستى سلول ممكن است بهعنوان تنظيم كنندهاى ردوكس در دريافت و بيامرسانى تغييرات ميدان مغناطيسى اهميت داشته باشند. ايشان معتقدند ميدان مغناطيسى

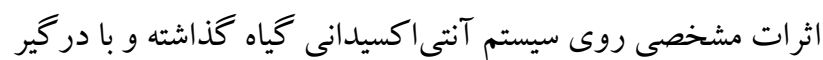
شدن ميدان مغناطيسى در واكنشهاى آنتىاكسيدانى آيويلاست، Cakmak ) باعث فائق آمدن سلول بر عدم توازن ردو كس مى .(et al., 2012 
Campos, P.S., nia Quartin, V., chicho Ramalho, J. and Nunes, M.A. 2003. Electrolyte leakage and lipid degradation account for cold sensitivity in leaves of Coffea sp. plants. - J. plant physiol. 160: 283-292.

Cakmak, T., Cakmak, Z.E., Dumlupinar, R. and Tekinay, T. 2012. Analysis of apoplastic and symplastic antioxidant system in shallot leaves: Impacts of weak static electric and magnetic field. - J. Plant Physiol. 169: 1066-1073.

Çelik, Ö., Büyükuslu, N., Atak, Ç. and Rzakoulieva, A. 2009. Effects of magnetic field on activity of superoxide dismutase and catalase in Glycine max (L.) Merr. roots. - Pol. J. Environ. Stud. 18: 175-182.

Chen, Y.P., Li, R. and He, J.M. 2011. Magnetic field can alleviate toxicological effect induced by cadmium in mungbean seedlings. - Ecotoxicology 20: 760-769.

Flórez, M., Carbonell, M.V. and Martínez, E. 2007. Exposure of maize seeds to stationary magnetic fields: Effects on germination and early growth. - Environ. Exp. Bot. 59: 68-75.

Flórez, M., Martinez, E. and Carbonell, M.V. 2012. Effect of magnetic field treatment on germination of medicinal plants Salvia officinalis L. and Calendula officinalis L. - Pol. J. Environ. Stud. 21: 57.

Haghighat, N., Abdolmaleki, P., Ghanati, F., Behmanesh, M. and Payez, A. 2014. Modification of catalase and MAPK in Vicia faba cultivated in soil with high natural radioactivity and treated with a static magnetic field. - J. Plant Physiol. 171: 99-103.

Javed, N., Ashraf, M., Akram, N.A. and Al-Qurainy, F. 2011. Alleviation of adverse effects of drought stress on growth and some potential physiological attributes in maize (Zea mays L.) by seed electromagnetic treatment. - Photochem. Photobiol. 87: 1354-1362.

Kavi, P.S. 1977. The effect of magnetic treatment of soybean seed on its moisture absorbing capacity. Sci. Cult. 43: 405-406.

Khazaie, H.R., Nadjafi, F. and Bannayan, M. 2008. Effect of irrigation frequency and planting density on herbage biomass and oil production of thyme (Thymus vulgaris) and hyssop (Hyssopus officinalis). - Ind. Crops Prod. 27: 315-321.

Ksouri, R., Megdiche, W., Debez, A., Falleh, H., Grignon, C. and Abdelly, C. 2007. Salinity effects on polyphenol content and antioxidant activities in leaves of the halophyte Cakile maritima. - Plant Physiol. Biochem. 45: 244-249.

Kumaran, A. and Joel Karunakaran, R. 2007. Antioxidant and free radical scavenging activity of an aqueous extract of Coleus aromaticus. - Food Chem. 97: 109-114.
Lichtenthaler, H.K. and Buschmann, C. 2001. Chlorophylls and carotenoids: Measurement and characterization by UV-VIS spectroscopy. In: Current protocols in food analytical chemistry, F4.3.1-F4.3.8. - John Wiley and Sons, Inc., New York.

Maffei, M.E. 2014. Magnetic field effects on plant growth, development, and evolution. - Front. Plant Sci. 5: 1-15.

Martínez, E., Carbonell, M.V., Flórez, M., Amaya, J.M. and Maqueda, R. 2009. Germination of tomato seeds (Lycopersicon esculentum L.) under magnetic field. Int. Agrophys. 23: 45-49.

Narwal, S., Bogatek, R., Zagdanska, B.M., Sampietro, A.D. and Vattuone, M.A. 2009. Plant Biochemistry. Studium Press Lcc, Texas, pp: 413-432.

Radhakrishnan, R., Leelapriya, T. and Kumari, B.D.R. 2012. Effects of pulsed magnetic field treatment of soybean seeds on calli growth, cell damage, and biochemical changes under salt stress. - Bioelectrom. 33: 670-681.

Radhakrishnan, R. and Kumari, B.D.R. 2013. Influence of pulsed magnetic field on soybean (Glycine max L.) seed germination, seedling growth and soil microbial population. - Indian J. Biochem. Biophys. 50: 312-317.

Reichling, J., Schnitzler, P., Suschke, U. and Saller, R. 2009. Essential oils of aromatic plants with antibacterial, antifungal, antiviral, and cytotoxic properties-an overview. - Forschende Komplementärmedizin/Res.in Complemen. Med. 16: 79-90.

Roshandel, P. and Azimian, F. 2015. Effects of magnetic field on growth and antioxidant capacity of Artemisia aucheri in normal or saline conditions. - Biol. Forum 7: 1095-1103.

Shine, M.B., Guruprasad, K.N. and Anand, A. 2012. Effect of stationary magnetic field strengths of 150 and $200 \mathrm{mT}$ on reactive oxygen species production in soybean. - Bioelectromagnetics 33: 428-437.

Thomas, S., Anand, A., Chinnusamy, V., Dahuja, A. and Basu, S. 2013. Magnetopriming circumvents the effect of salinity stress on germination in chickpea seeds. Acta Physiol. Plant 35: 3401-3411.

Vinson, J.A., Hao, Y., Su, X. and Zubik, L. 1998. Phenol antioxidant quantity and quality in foods: vegetables. - J. Agri. Food Chem. 46: 3630-3634.

Yinan L, Yuan L, Yongquing Y, Chunyang L. 2005. Effect of seed pretreatment by magnetic field on the sensitivity of cucumber (Cucumis sativus) seedlings to ultraviolet-B radiation. - Environ. Exp. Bot. 54: 286-294.

How to cite this article:

Mohammadi, R., Roshandel, P. and Tadayon, A. 2019. The effects of magnetopriming on the growth, physiology and antioxidant systems in hyssop - Nova Biol. Reperta 6: 106-115.

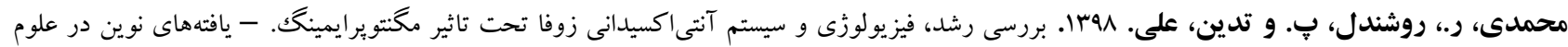

